\title{
Investigating everyday measures through exploratory talk: whole class plenary intervention and landscape study at grade four
}

\author{
Sharada Gade ${ }^{1}$ Charlotta Blomqvist ${ }^{2}$
}

Received: 20 May 2014/Accepted: 26 August 2016/Published online: 17 October 2016

(C) The Author(s) 2016. This article is published with open access at Springerlink.com

\begin{abstract}
We report an exploratory talk based, whole class plenary intervention, in relation to students' understanding of everyday measures and measurement, in a grade four classroom at a grade 4-6 school in Sweden. Extended, project related, teacher-researcher collaboration forms basis for such cultural historical activity theory or CHAT based efforts. As formative intervention, the conduct of the plenary is not pre-determined but embedded in ongoing curricular realities, with the agency of students and teacher promoted, pedagogical ideas reutilised and the role of researcher viewed as supporting design and growth of the intervention. Under Charlotta's guidance as teacher, the plenary is opportunity for her students to examine improbable scenarios such as, Can Eva and Anton measure the length of Sweden on foot, Can Lars and Iris measure their age in decimeters. A zone of proximal development is created, in which students make the transition from spontaneous to scientific concepts and learn how various units of measurement are objects-that-can-beused-for-certain-purposes. With opportunity for critical and reflective inquiry, in a plenary designed to lead development, Charlotta's students look beyond the making of rote measurements and articulate a theory of measure in nascent terms. Such a landscape of teaching-learning is finally understood in terms of the nature of talk that was facilitated, the manner of pedagogy utilised, the style of teaching exercised and the kind of learning that was demanded of her students.
\end{abstract}

Keywords CHAT perspectives · Formative intervention - Developmental education · Dialogic inquiry $\cdot$ Exploratory talk · Everyday measures and measurement · Landscape study

Lead Editor: I. Martins.

Sharada Gade

Sharada.Gade@umu.se

1 Umeå University, Umeå, Sweden

2 GrisbackaPrimary School, Umeå, Sweden 


\section{Svensk sammanfattning}

I denna artikel rapporterar vi om en intervention i en klass i årskurs fyra i Sverige. Interventionen baserades på ett, i helklass genomfört, explorativt samtal (Barnes 2008) rörande elevernas förståelse av storheter, enheter och mätningar i vardagen. Denna intervention var en del av ett lärar- och forskarsamarbete grundat i kulturhistorisk aktivitetsteori (Gade 2015). Den var inte förutbestämd utan ingick som en naturlig del i de pågående undervisningsaktiviteterna som en formativ intervention (Engeström 2011). Inom formativa interventioner eftersträvas elevers och lärares agens (agency) samt återanvänding av pedagogiska idéer. Forskarens roll ses som stödjande i utvecklingen av undervisningsaktiviteterna. Under läraren Charlottas ledning (Mercer and Dawes 2008) var helklassdiskussionen en möjlighet för eleverna att undersöka osannolika scenarier såsom "Kan Eva och Anton mäta Sveriges längd med foten" och "Kan Lars och Iris mäta sin ålder i decimeter." En proximal utvecklingszon skapades för eleverna, där en övergång från vardagliga till vetenskapliga begrepp skedde (Karpov 2003b) och där eleverna kunde få insikt om att olika storheter och enheter är objekt-som-kan-användas-för-vissa-ändamål (Stetsenko 1999). Undervisningsaktiviteterna var designade för elevernas utveckling (Wells 1999) och gav möjlighet till kritiskt och reflexivt undersökande. Under Charlottas guidning såg eleverna bortom rutinmässiga mätningar och formulerade i begynnande termer en teori om mätningar (Lehrer et al. 2003). Detta landskap av undervisning-lärande förstås slutligen i termer av det samtal som främjades (Pierce and Gilles 2008), den pedagogik som användes (Dalton and Tharp 2002), undervisningens karaktär (Alexander 2008) och det lärande som Charlottas elever förväntades uppnå (van Oers 2008).

As researcher and teacher we report a whole class plenary intervention, conducted in a grade four classroom at a grade 4-6 school in Sweden. In doing so we examine students' use of exploratory talk (Barnes 2008) in examining their understanding of everyday measures and measurement. Two aspects of extended, teacher-researcher collaboration underpin design and conduct of this plenary. First, this intervention is the third and culminating one in a project conceived by Lotta, as Charlotta is known, to promote students' communication in mathematics, funded by The Swedish National Agency for Education (Skolverket Dnr 2009:406; http://www.skolverket.se). Taken together these interventions exemplify what Yrjo Engeström (2011) terms Formative Intervention, four features of which distinguish them from design based studies - their starting point is not pre-determined but embedded in curricular realities, the agency of all participants is promoted, the pedagogical ideas utilised are redeployed subsequently and the role of the researcher is viewed as supporting design and growth of the intervention over time. Our adopting such an approach in Lotta's project, had the advantage of locating our interventions in the content area she was dealing with as teacher, in her curricular routines, causing minimum hinderance to her teaching obligations. Where in the first, we had students' rectify their faulty use of the mathematical = sign the curricular topic dealt with all four arithmetical operations (Gade 2012), in the second, students posed mathematical problems by making conscious use of vocabulary found in their mathematics textbook (Gade and Blomqvist 2015). In line with drawing upon cultural historical activity theory or CHAT perspectives, we used slips of paper (lappars in Swedish) to explicitly mediate either intervention, which in addition to implicit mediation by the Swedish language used, enabled students to participate in mathematical activity under our supervision (Wertsch 2007). This enabled us to lead the development of Lotta's students, by creating zones of proximal development as 
they worked in pairs in either intervention (van Oers 2009). We reutilised the same pedagogical idea in Lotta's plenary intervention, wherein everyday measurement was curricular topic. The second aspect that underpinned the design and conduct of Lotta's plenary, was the extended nature of our collaboration as teacher and researcher, one whose historical trajectory Sharada has identified as expansive learning activity (Engeström 2001). Such activity began with Sharada being participant-observer in a pilot study conducted with Lotta's prior grade six students (Gade 2010) and culminated in our co-authorship of subsequent research reports. Far from being a consumer of research conducted by others, in doing so, Lotta steered her plenary in a theoretically informed manner and contributed to CHAT theorising as teacher (Gade 2015). As researcher, Sharada too drew on five insightful perspectives for design and conduct of Lotta's plenary. First Neil Mercer's (2004) writings wherein he discusses classroom talk as both cultural and psychological tool. Advocating use of exploratory talk, a category we elaborate in the next section, Mercer (2013) also seeks the study of goal-directed collective thinking as means to better grasp the development of individual students. Second, we recognise the central role of mediation in CHAT perspectives, either by one's own consciousness (Bakhurst 1986), one's peer (Kozulin 1990) or one's teacher (Moll 2001) while constructing knowledge within instructional activity. The conduct of these is further informed by James Wertsch (2007) who makes a distinction between implicit and explicit forms of mediation. While the former takes place in internal, invisible and implicit ways as when using language, the latter takes place in an external, visible and explicit manner as with use of cultural artifacts like measuring instruments. Drawing upon perspectives of explicit mediation we had Lotta's students use lappars, with say arithmetical operations or textbook vocabulary inscribed upon them, enabling them to take part in collaborative activity and make sense of canonical ways of mathematical knowing. Third, we draw upon Gordon Wells' (1999) notion of understanding, as being personal and immediate, besides holistic and intuitive, within knowledge building activity. Like Mercer, Wells too seeks interventions which enable students to examine and achieve beyond what is given, mundane, normative and privileged. It was such guidance which led Sharada to design questions which related to improbable scenarios in which measurements could be made, which Lotta was ready to try out in her teaching e.g. Can Eva and Anton measure the length of Sweden on foot, Can Lars and Iris measure their age in decimeters. Fourth, in Lotta's students discussing improbable scenarios of measurement, first in pairs and then collectively, we attempted to orchestrate a sociological microcosm of learning, the importance of which Harry Collins and Trevor Pinch (1993) draw attention to in The Golem: what everyone should know about science. Their portrayal of a group of students ascertaining the temperature at which water boils in a science classroom, exemplifies the spirit of what we set out to achieve,

One thing is certain: almost no-one will get $100{ }^{\circ} \mathrm{C}$ unless they already know the answer, and they are trying to please the teacher. Skip will get $102{ }^{\circ} \mathrm{C}$, Tania will get $105{ }^{\circ} \mathrm{C}$, Johnny will get $99.5{ }^{\circ} \mathrm{C}$, Mary will get $100.2^{\circ} \mathrm{C}$, Zonker will get $54{ }^{\circ} \mathrm{C}$, while Brian will not quite manage to get a result; Smudger will boil the beaker dry and burst the thermometer. Ten minutes before the end of the experiment the teacher will gather these scientific results and start the social engineering. Skip had his thermometer in a bubble of super heated steam when he took his reading. Tania had some impurities in her water, Johnny did not allow the beaker to come fully to the boil, Mary's result showed the effect of slightly increased atmospheric pressure above sea-level, Zonker, Brian and Smudger have not yet achieved the status of fully competent research scientists.... That 10 min renegotiation of what really happened 
is the important thing. ... These are theorists hovering around, like the school teacher, to explain and try to reconcile. ... There is nothing wrong with this; the only sin is not knowing that it is always thus. (pp. 150-151)

Finally, in allowing for goal-directed thinking and explicit mediation of students' understanding, the design and conduct of Lotta's plenary intervention enables us to study the landscape of teaching-learning that was brought about, in terms of four inter-related aspects - the nature of talk that was facilitated (Pierce and Gilles 2008), the manner of pedagogy that was utilised (Dalton and Tharp 2002), the kind of teaching exercised by Lotta (Alexander 2008) and the kind of learning demanded of her students (van Oers 2008). Taken together, these perspectives enable our study to ask-In what manner did Lotta's students use exploratory talk to examine their understanding of everyday measures and measurement? In what manner were talk, pedagogy, teaching and learning related in the landscape of teachinglearning that was brought about in her plenary? Towards these aims in sections that follow, we first examine CHAT based theoretical underpinnings, next describe the methods we deployed, thereafter evidence talk which transpired in Lotta's plenary, before dwelling on the landscape of teaching-learning that was brought about, in conclusion.

\section{Theoretical underpinnings}

Many a CHAT perspective underpins the three interventions of which Lotta's plenary forms a part. Termed developmental education, Bert van Oers (2009) for example forwards an approach whose aims are not to make students fit into a knowledge society, but become responsible and critical members in a democratic one, where their identities are transformed in the process. In providing cultural tools with which to participate, meaningful instructional activity van Oers adds, deals not only with textual activity, but also promotes a reflective attitude in the mastery of subject matter skills and understanding. Drawing on Vygotsky, van Oers views good education to always be one step ahead of pupils' development, where by drawing on Leont'ev, he points to the risk associated with rote learning in dehumanising students and robbing them of their agency and identify. In line with van Oers, Lotta's plenary enabled her students to examine various scenarios of measurement however improbable, besides foster an identity either as a skeptic say or knowledgable peer, who was able to further collective understanding in the plenary. In student pairs deliberating about ten questions, Lotta's plenary was also able to instantiate what Gordon Wells (1999) terms as dialogic inquiry, where students' knowledge is viewed as not existing outside their plenary, but recreated, modified and extended within the activity of knowing. While such manner of inquiry was mediated, both explicitly and implicitly, by students' familiarity with measuring instruments like say a meter ruler or weighing scale (Wertsch 2007), Lotta's students had opportunity to engage with knowledge building at a remove from making concrete measurements in their classroom or playing field. Wells goes on to argue that although students' first-hand experience provides essential basis for their understanding, the intuitive aspects of personal experience are extended and reinterpreted only via dialogic inquiry, wherein informational resources and representational tools of culture are critically employed for collective knowing. Speaking from experience of building communities of dialogic inquiry in classrooms, Wells (2002) mentions two ideas which he finds generative. First, that of improvable object, which is a problem encountered in practical situations which can be improved through collaborative action and dialogue. We consider students' understanding of measures and measurement to be the 
improvable object in Lotta's plenary. Second, spiral of knowing which traces the many roles speaking, writing and other modes of communication play, in thinking about and building collective knowledge around an improvable object. In having made measurements in the concrete and worked at textbook exercises, Lotta's plenary was opportunity for them to reflect on their prior experiences in a spiral of knowing. Wells finally identifies two problems which hinder the realisation of dialogic inquiry in educational practices. First, commodification of knowledge, which fails to distinguish between knowledge and knowing. Echoing problems associated with a banking conception of education (Freire 2005), Wells argues that educational systems mistakenly equate representations of knowledge with the reflective activity of knowing, wherein knowledge objects can be improved within a spiral of knowing. Second, Wells points to the unwillingness of educational systems, to accept diversity both in students as well as their learning trajectories. A one-model-fits-all, transmission and accreditation approach, he argues, fails to honour students and their individual potential. In not claiming to entirely overcome either concern, we view Lotta's plenary, wherein her students had opportunity to reflect on their knowing and develop individual identity, to be a decisive step in the direction Wells and van Oers point.

Two arguments made by Yuriy Karpov inform those made by van Oers and Wells. The first alludes to leading activity, which draws attention to the nature of instructional activity which when conducted brings about maximum development in students. In the course of mediation within these activities, children develop new motives as they transit to their next age period and leading activity. Karpov (2003a) argues emotional communication with caregivers to be leading activity of infants, whereby they become interested in the external world because it is presented to them by loving adults who act as mediators. The leading activity for children in their second and third years is object-centered, by which time they develop the ability to regulate their own activity through the use of private speech. Via socio-dramatic play, children transiting to middle childhood overcome egocentric positions and become capable of engaging in symbolic thought. Learning in educational settings is best suited for middle childhood, when learning of scientific concepts and development of formal-logical thought is organised and mediated by teachers. Interaction with peers is similarly leading activity for adolescents, taking part in which they engage in self analysis, develop identity and become capable of formal-logical thought. Following Karpov (2003a) Lotta's plenary offered organised guidance for her students in relation to everyday measures and measurements. Karpov (2003b) second, explains how students acquire scientific concepts in guided activity by drawing on the Vygotskian distinction between scientific and spontaneous concepts. Spontaneous concepts which result from generalisation of everyday personal experiences, he explains, are not necessarily conscious and could even be wrong due to lack of systematic instruction. Scientific concepts on the other hand result from generalisation of humankind's experience and could become conscious under meaningful instruction. Vitally, it is scientific concepts which could create the zone of proximal development for students' spontaneous concepts, transforming the latter into conscious entities, independent of personal experience. By making the transition between spontaneous and scientific concepts children develop formal-logical thought and make the transition from practitioners to theorists in addition. Taken together, Karpov provides methodological and theoretical rationale for the conduct and study of students' development, which van Oers draws attention to. On the vital role of cultural tools like units and measuring instruments in such a plenary, Anna Stetsenko (1999) highlights two important aspects. First, that the very function of various cultural tools as objects-that-can-be-usedfor-certain-purposes, is gathered through social interaction with those who posses such meaning and knowledge. Second, that only when one is able to study the bridge between 
social interaction, cultural tools and the formation of a zone of proximal development, is it possible to understand why learning plays a leading role in development. This is so because, via learning and within meaningful social interaction and mediation by adults and peers, a child has opportunity to act and master the use of relevant cultural tools. Such manner of learning in turn awakens, various internal processes of development in a child.

The notion of exploratory talk which we centrally deploy in our study, follows the work of Douglas Barnes (2008) who differentiated this talk from presentational talk. While the latter is used say when children adjust the language, content and very manner of their talk while responding to a teacher demanding conformance, the former is hesitant, even incomplete, since it enables the child to try out ideas, hear how they sound when spoken out loud and see what others make of them. Four arguments Neil Mercer makes, extend Barnes' notion of exploratory talk and shed greater light on Lotta's plenary conduct. First, his arguing that students need guidance to use talk and work together, so that their personal experience could become part of the communicative process in which they account for themselves (Mercer 2002). Second, his highlighting the role of teachers in establishing and holding ground rules in place, so that students can investigate the underlying scientific concepts (Mercer and Dawes 2008). Third, that an analysis of exploratory talk needs to be temporal, making it possible to study how talk progresses empirically, dynamically and in a theoretical manner (Mercer 2008). Finally, Mercer (2013) lists three mechanisms by which students could engage in goal-directed collective thinking-appropriation of each other's strategies, co-construction of ideas by utilising robust and generalisable strategies and transformation of ongoing debate in a critical and rational manner. Such approach to analysis of talk is informed from wider research in science education which advocates the use of talk to do science in the medium of language when students observe, hypothesise, analyse, report findings (Lemke 1990) besides have opportunity to explore one's individual understanding (Mortimer and Scott 2003). Mathematics education research also recognises the need for students to overcome taking measurements in a rote fashion, with focus on procedural aspects alone (Clements and Sarama 2009). While procedural aspects could include say measuring, pacing, inscribing, and symbolising, more conceptual aspects could include numerical correspondence between magnitudes and attributes of what was being measured, arrangement in succession of subdivisions of a unit and also that standard measures are made up of identical units (Lehrer 2003). The need for students' to articulate a theory of measure, beyond making various acts of measurement, is articulated once again by Lehrer, Jaslow and Curtis (2003),

A theory of measure develops from a grounding in contexts that highlight recognizable goals and functions but extends beyond these contexts to provide flexible adaptability to novel situations of application (e.g. new circumstance of measure) and to serve as a foundation for future learning, so that students' learning does not remain bound to the tools or situations that were instrumental in helping them develop understanding in the first place. (2003, p. 100)

We take the many aspects we outline above to help us nuance the manner in which both Lotta and her students took part via talk in her plenary. The outcome of such a combined analytical repertoire is in line with the spirit of ascending from the abstract to the concrete in CHAT research, where any phenomena is understood as concrete and studied from as many perspectives as possible, so as to ascertain the many inner laws that determine it's very existence (Luria 1979). Our adopting such an approach persuades us to examine the very landscape of teaching-learning which Lotta's plenary brought about, whose reality we attempt to understand in terms of four inter-related aspects. First, the kind of talk used in 
Lotta's plenary as one of five recognised categories, including social talk, presentational talk, exploratory talk, meta talk and critical talk (Pierce and Gilles 2008). Second, the kind of pedagogy Lotta herself exercised, in line with five categories presently recognised such as joint productive activity, developing language and literacy across the curriculum, making meaning connecting school to students' lives, teaching complex thinking and teaching through instructional conversation (Dalton and Tharp 2002). Third, the kind of teaching Lotta utilised in her plenary, in terms of categories such as transmission, initiation, negotiation, facilitation, acceleration as well as technique (Alexander 2008). Finally, the manner of learning Lotta expected of her students, in terms of four categories presently recognised, including learning to perform, learning to make meaning, learning to participate and learning to be (van Oers 2008). In due course, Sharada intends to make a comparative study of the landscapes of teaching-learning that became possible in the conduct of the three interventions which constituted our Formative intervention (Engeström 2011) besides a pilot which preceded these in extended collaboration within Lotta's project.

\section{Methods of study}

The extracts presented in this paper, enable us to showcase how Lotta guided her students' use of exploratory talk and the manner in which her students used exploratory talk to examine their own and collective understanding of everyday measures. Towards these aims we draw upon constructs outlined in the previous section and conduct a temporal analysis (Mercer 2008). Before outlining the six stages in which we conducted such manner of analysis we find it pertinent to mention four relevant aspects. First, that we chose an easyon-the-eye transcription protocol, to highlight the flow of students' arguments across its trajectory. Second, while presenting students' responses, we left out talk extraneous to it's gist, like an electrician's visit or a phone call received by the class teacher from a concerned parent. Third, we retained some Swedish utterances to convey the original flavour of students' talk, including explanatory comments where necessary. Finally, we deployed three levels of triangulation in our efforts-time triangulation across its entirety, student triangulation of individual as well as collective participation and investigator triangulation which was aided by our efforts as teacher as well as researcher (Denzin 1989). The empirical data collected for such manner of triangulation includes Sharada's field notes, her audio-recording of the plenary besides her audio-recording of discussions both of us had while transcribing and translating the audio-recording of the plenary. Audio-recordings of conversations which took place at various stages of our collaboration were also drawn upon, the content of which is discussed in Gade (2015).

The six stages in which our analysis proceeded was as follows. First, Sharada listened to her audio-recording of the plenary, to confirm its veracity for scientific reporting. Lotta next listened to the same, enabling her to reflect on her own participation as well as that of her students. It was only in the third stage that we listened to the audio-recording together, an event that enabled us to revisit the plenary with the emotion and fun that accompanied and energised its very conduct. Fourth, we together identified utterances of talk with respect to spontaneous and scientific concepts (Karpov 2003b) and the kind of guidance Lotta offered (Mercer and Dawes 2008) besides the identity her students displayed (van Oers 2009). In was only in the fifth stage that we paid special attention to the theory of measure which Lotta's students were attempting to articulate. The sixth and final stage was 
a theoretical one in which Sharada understood Lotta's plenary as a whole, one constituted by categories recognised in research of talk, pedagogy, teaching and learning. In conducting such a trajectory of analysis, we have been able to satisfy five criteria-democratic validity honouring our voice as teacher and researcher, besides those of Lotta's students, outcome validity by eliciting the theory of measure, however nascent, as this emerged in the plenary, process validity in Lotta's ability as teacher to draw upon CHAT theory to conduct her plenary, catalytic validity in her being able to co-author the content of our research reports and dialogic validity in intersubjective talk being central throughout teacher-researcher collaboration, design and conduct of our intervention and its reporting (Anderson, Herr and Nihlen 2007). In turning to evidence talk with respect to ten questions that were discussed in the plenary, we once again preface four issues which are relevant. First, we present extracts of talk in English and draw on Lotta's interpretation of talk as teacher and native speaker of Swedish. Second, we draw on conversational exchange that transpired in English between us during our analytical sessions. Third and by design our questions addressed students by their name allowing us to personalise each question, even though we annonymise students in our current reporting. Finally, we mention that unlike in the English usage where measurements are made in seconds or kilometers say, in Swedish usage measurements are made with respective units. While conducting her plenary Lotta in addition stationed herself in front of the class, facing her students, with the whiteboard behind her and successive student pairs standing beside her as they addressed their peers. Each student pair also had the possibility of discussing the question assigned to them at their desk, before jointly presenting their exploratory arguments in Lotta's conduct of the plenary. We now present the trajectory of talk as this transpired in Lotta's plenary, focussing upon common themes that seemed to emerge in the ten questions discussed.

\section{Lotta's plenary conduct}

Lotta's conduct of the first question, Can Eva and Anton measure Sweden's length on/with foot? set the stage for three aspects in her plenary. First, she made sure her students felt comfortable working via talk and not with their textbook, as they had come to expect. Second, she took time to establish ground rules which ensured her plenary transpired and did not fall apart with students' disinterest. Third, she was able to guide her students' use of exploratory talk to examine their understanding of measurement in various scenarios. This began as follows,

Lotta Now you have to explain to your friend, is it possible and why is it possible, or maybe it is not possible and can we do it in another way... Read the questions and then you have to answer it

Karin And then do we have to say something and if it is an answer can I say it

Lotta Yes, of course... Is it true that Sharada could be have written these questions?... And you must think about the questions and then you are coming to the front of the class... How will you think if it is not true and we have to listen very very carefully, you have to concentrate

On allowing Eva and Anton to read the question for the first time,

Lotta Once more

Eva Can Eva and Anton measure Sweden's length with/on foot

Many Nooo...@@ [Laughter] 
Lotta No, no, not now... Eva and Anton will attempt this question... only them first [??] It works (Det går)

After re-reading the question, we observed Eva to take paces between Lotta, the front row of desks and the whiteboard. While Noel, a student from the audience, guessed Eva's pace to be a meter we observed Anton to walk with his feet end to end in addition. The ensuing talk included,

Liam You have to go straight ahead

Ulla What if you go into a building

[??] Then you go over the house

Lotta Noel! Do you have anything good to say

Noel And you can go through the house... and you can go inside the house and jump off the balcony

Leon And what if it is a high building

Nils If you have a map, you can take that, you can look how much a foot is and use the scale of the map

Upon Nils' suggestion Lotta pulled down the map of Sweden from the false ceiling. Nils and Lotta then discussed the manner in which the scale of a map could be used before concluding,

Lotta Good, so you could measure Sweden's length on/with foot/feet

Noel It is possible to measure Sweden's length with feet, but its a lot of work

Lotta At first even I did not think it was possible

Lotta Maria and Nelly its now your turn... you must listen

The abstracts above enable us to highlight many aspects, the first of which relates to ground rules that Lotta established and held in place during her plenary conduct (Mercer and Dawes 2008). Via these Lotta instilled order and exercised her authority, nominating which student could speak, how each student was to respond and also when. We observe Eva and Anton to whom the question was addressed, to present their arguments to their peers, even as Noel commenced his participation as a peer from the audience in the classroom. We find Lotta to encourage her students to verbalise their thoughts, letting them hear how they sounded and infer what others made of them (Barnes 2008). Such attempts led them consider the practicalities of measuring the length of Sweden on foot, which led them to speculate about walking into a high building, the need to jump off a balcony if needed, besides estimate the amount of work that involved. While such inquiry drew on personal experience there was opportunity too for Lotta's students to engage in a knowledge building exercise that was at a remove from making measurements in the concrete (Wells 1999). They could critique collective understanding of the measurement in question, which became their improvable object of inquiry (Wells 2002). The identities of two students as learners emerged, one that played a significant role throughout Lotta's plenary (van Oers 2009). Where Noel was skeptical of making measurements in improbable scenarios and as we shall see later on, Nils became anchor, steering discussion through a space in which anything could happen. The manner in which students tried to bridge spontaneous and scientific concepts is also exemplified in Eva taking paces and Anton walking with his feet end to end to externalise their personal knowledge, besides Nils suggesting that the scientific concept of scale in a map could be used to deal with the question at hand (Karpov 2003b). 
While Lotta's students explored their understanding via talk within her ground rules, the plenary discussion in the next three questions allowed them to deliberate on aspects relating to appropriate scale and appropriate unit while making measurements. The first of these relating to, Can Maria and Nelly measure their height in/with kilometers? began as follows.

Lotta Can you measure your height in/with kilometers

[??] Yes

Leon Zero [or naught] point (Noll comma)

Liam It doesn't work (Det går inte)

Lotta But kilometers can be decimal numbers

Lena But they are not kilometers in height [loudly and pointing to them]

Lotta You are not a kilometer high because then you will be very very tall... How are you thinking girls

Nelly I think we can fix this with mini-kilometers

Lotta How do you think about mini-kilometers... maybe it is like how Leon said

Leon Zero point... zero point, zero point one maybe

With Maria and Nelly's participation being quite minimal, Lotta concluded,

Lotta Maria are you satisfied... are you one kilometer tall!

Even as we discuss the issue of scale in a short while, the above extract refers to Maria, a student with special needs, who was unsure of her participation. While Lena from the audience exclaimed that Nelly did not appear a kilometer tall in response to the question, students' understanding of the magnitude of a kilometer as unit was mediated by Lotta as teacher, in suggesting that students could use a decimal fraction of the same measure. Such mediation helped her clarify how a kilometer unit was object-that-can-be-used-for-certainpurpose (Stetsenko 1999). Her mediation in more concrete terms transpired during students' responses to the following question, Can Liam and Meja measure the height of the classroom in/with decimeters? which transpired as follows.

Meja Can Liam and Meja measure the height of the classroom in/with decimeters

Many Yaaa... it works

Lotta It works... Meja and Liam we have measured this in the classroom haven't we... how many meters was it Lena [Addressing Lena who appeared distracted]

Lena The height of the classroom was $8 \mathrm{~m}$

Lotta Is it 8 like this [Showing her class a wooden meter ruler]

Lena No it wasn't

Nils No it was like three of these [widening his arms to show] It was like $3.09 \ldots$ I know, it was $39 \mathrm{dm}$

Lotta Noel... if it is $3 \mathrm{~m}$ high... how many decimeters is that [As she found him to roam around]

The above extract shows Lotta challenging Lena's estimation of the length of a standard meter as unit, by showing her a meter ruler that was available in their classroom. Such display and mediation led Lena to accept her mistake and retract what she said. Placing his palms a decimeter apart on his desk, Nils then displayed his estimate of a decimeter length and recalled the height of the classroom to be thirty nine decimeters. Such mediation by Lotta and Nils helped create their zone of proximal development, in which the scientific concept of a meter and decimeter lead the development of spontaneous concepts which Lena held (Karpov 2003b). We argue such a zone to be created once again in relation to the 
question, Can Mikael and Elsa measure daytime in/with kilograms? when Lotta's guidance as recounted below, included partnering with Elsa, since Elsa's designated partner Mikael had swimming lessons to take.

Elsa No [very softly] we can't measure time with kilograms as we measure other things with kilograms

Lotta As when you measure your weight or when you are baking cookies... Kilogram is a measure for weight

Lena If the time is 9 o'clock you can say its is 9 kilograms

Lotta If the time is 9 o clock you can say its is 9 kilograms

Noel What? I don't understand anything (Vad? Jag fattar ingenting!)

Upon further attempts by other students at this question, Leon responds

Leon I know a difficult way to advance this answer... how to measure time in kilograms... the whole time the particles change and we can measure the weight of the particles count how many particles there are... over time

[??] Eeeeee! [Many acknowledging this explanation as weird and strange sounding]

The three questions just discussed highlight the manner in which Lotta's students attempted the transition between spontaneous and scientific concepts, in relation to appropriate units and scale that are needed for making any measurement. Where a kilometer was recognised as not appropriate to measure a peer's height, its decimal equivalents came up for consideration. A decimeter also fell short of measuring the height of the classroom, for which almost forty times the unit was considered adequate measurement. Such manner of discussion allowed for two aspects, it allowed students to be attentive and critical, besides develop a reflective attitude (van Oers 2009) one which asked them to look beyond normative notions of measurements that could be made in a rote manner (Clements and Sarama 2009). The challenge however was to measure quantities with units that were perceived as incompatible, like duration of time in units of weight. It was this last that brought forward Leon's knowledge of radioactive particle decay to the fore, one which was way beyond Lotta's curricular expectations. Such knowledge was also shared with ease and may not have surfaced at all, if Lotta's plenary had not become an activity of knowing for them (Wells 1999).

Located midway through Lotta's plenary, discussion in relation to the question, Can Lars and Iris measure their age in/with decimeters? was a turning point in more ways than one.

Lars Can Lars and Iris measure their age in/with decimeters

Lotta Can Lars and Iris measure their age in/with decimeters

Many Noooo

Lotta You should think about it for a while

Nils Maybe

[??] It works (Det går)

Lotta Lars and Iris will answer, if it is possible to measure one's age in decimeters Lars and Iris will answer first

Lars [Inaudible]

Noel It doesn't work (Det går inte)

Nils If you measure, just like Lars says or what Iris... If you are ten decimeters long... could't you say as Lars and Iris are suggesting that you are for example 10 years old... 
Lotta [Inaudible]

Nils Ten decimeter years

Leon Ten Dennis decimeter years!

To go along with students' talk Lotta then gives example of clothing sizes, yet is interrupted

Mark If you are 30 years old then you just count thirty decimeters. If you are 10 years old then you reckon ten decimeters

Leon Can one say one is thirty decimeters old

Mark If you are 30 years old... you say thirty decimeters. In that way you measure age

Noel What! How are you thinking! I don't get it

Lotta When we have thirty decimeters... We must hear what Mark is saying and it is very difficult to hear what Mark is saying if all of you talk at the same time

Noel You are insane! (Du är inte klok!)

Lotta You mean that someone who is 30 years old is thirty decimeters tall?

Leon This is just like Lena measuring time in kilograms!

Noel I don't get it! (Jag fatter inte!)

After further exploration Nils ends their collective responses with

Nils Nobody understands that... I have said this throughout the lesson [Addressing Lotta loudly]

Lotta I haven't heard you Nils [Meaning she should have listened to him all along]

Two aspects are worthy of note. First, Nils' response of Maybe by which he seemed to suggest that the improbable scenarios being engaged with in Lotta's plenary, could be considered as probable. We argue this to be the case based on his suggesting to Lotta towards the end of the same extract, that nobody seemed to understand what was happening in her plenary. In fact in discussing the next question, Nils specifically alludes to the plenary as a space in which anything can happen. Leon's imaginary unit of Ten Dennis decimeter years! can also be perceived in the same spirit. Second, we see nascent beginnings of a theory of measure emerge in the above extract (Lehrer et al. 2003). Suggested at first by Nils and articulated more forcefully by Mark, both students seemed to suggest that one could correlate the magnitude of a physical quantity with the number of units in which any measurement was being made.

Lotta's plenary discussion in the three next questions evidences how students were beginning to find creative ways by which the taking of measurements in improbable scenarios suggested could be carried out in reality. We find such imaginative attempts made with respect to, Can Mark, Karl and Leon measure their friendship in/with deciliters? as below,

Mark Can Mark, Karl and Leon measure their friendship in/with deciliters

Many@@@ [Laughter]

Lotta Now you think about this, if you can

Ulla Leon don't come up with something strange

Nils Maybe you can measure your friendship in space... remember anything can happen in space

Lotta Ok can we measure friendship in deciliters?

Mark We have a silly idea

Leon This is a lot of work... (Mycket jobbigt) 
Mark We must cut one's head and see how much friendship there is inside the head

Nils Or you can see how foolish or dumb you are

After drastic suggestions offered by Mark the following measures of friendship emerged

Lotta If you see these three boys... can we measure how good friends they are

Nils Noo! I give it a chance, if you see Mark's friendship with Leon has a typical value of 0.7 and with Karl $10.7 \ldots$ the two of them are never together and the other two are always together

Leon Excuse me, excuse me

Jan And with Liam minus 20.5!

When asked to quantify friendship, the above extract evidences how Lotta's students suggest new as well as dark ways to address the problem at hand. While Mark's team suggests cutting off heads to view friendship present inside them, Nils while shooting down this drastic idea suggests magnitudes of 0.7 for weak friendships, 10.7 for stronger ones and minus 20.5 to represent a lack of friendship between Mark and another student Liam. Yet a correspondence seemed to be apparent between the magnitude of friendship and its existence in reality. While addressing the next question, Can Jan and Karin measure the length of a chewing-gum in/with kilometers? the manner in which chewing-gum could be measured in kilometers was demonstrated by Jan who showed how gum could be pulled out from his mouth and measured. Procedural aspects of measurement were examined once again with, Can Ulla and Sara measure a football field in/with inches (tumen)?

Sara But it will take a long time (ganska lång tid)

Lotta But it works, isn't it... now Nils

Nils I know there is an English measure which is called inch and it is exactly $2.57 \mathrm{~cm}$

Adam Is it the whole thumb or [Showing thumbs being placed end to end, like feet]

Nils $\quad 2.57 \mathrm{~cm}$ is one inch... If the football field measure 60 meters, you take 60 and multiply it by $100 \mathrm{~m} .$. it works [We think Nils is measuring area of the football field]

Leon Yes, you can take 60 and multiply by 100

Nils And so it works

Lotta And Lars says, you can measure your TV with inches

Lotta's plenary talk in both the questions just discussed, sheds light on the CHAT contention that scientific concepts both mediate and create the zone of development for spontaneous concepts. As evidenced in the abstracts above Lotta's students used positive and negative integers as scientific concepts to represent the presence or absence of friendship between student peers. The English inch was also used to mediate the metric length of the Swedish tumen. As teacher Lotta drew attention to Lars' observation, that TV screens were measured in inches. Each of these examples we find, could well be the practical issues which students deal with while making a transition between practitioner and theorist, a bridge which parallels the Vygotskian transition between spontaneous and scientific concepts (Karpov 2003b).

Responses by Lotta's students to the two final questions in the plenary seemed to help them arrive at a theory of measure, however nascent it's form. In response to, Can Olof and Nils measure the weight of a horse in/with seconds? Lena's attempts to correlate the magnitudes of two quantities not commonly used to measure one another as follows, 
Lena If you in the future... have a thing for example which can measure... when the horses are jumping... maybe you measure that in seconds... its a thing... on their obstacle and if the horses are jumping over the obstacles then we can measure the weight

Anton Can't I say something now

Anton You can lift the horse by a crane and put it on a weighing scale in seconds and you take it off...

Even as we point to Anton adhering to Lotta's ground rules, waiting patiently for this turn after the his participation in the first question, in the final question we find Nils break from the imaginative space, one he acknowledged the presence of early on. While debating, Can Lena and Noel measure milk in/with minutes? Nils asked that measurements be made, not in a space where anything could happen, but as was routinely done, in a common world that everyone seemed to share.

Lena You could maybe... pour milk from a packet. Then maybe you can pour very slowly... in minutes. And then you pour it into a cup. And in that cup you measure how, how ...how many minutes

With Noel remaining silent during this period, Lotta sought her students' suggestions

Lotta Anyone else having any other idea

Nils I know, one can measure in volume

Lotta So one can measure volume, yes. So one can measure milk in liters

Nils As is common! (Som vanligt!)

Lena's response as well as Nils' suggestion brought closure not only to Lotta's guidance of her students' use of exploratory talk (Mercer and Dawes 2008) but also their own use of talk to examine their understanding of everyday measures and measurements (Barnes 2008). Sharada's field notes, relating to this point of time in the plenary, show Lotta ending her lesson by asking students to respond once again to each of the ten questions, whose responses she recorded with tally marks under the words Yes and No on the whiteboard. The result of this exercise was that most students responded yes to questions in which the scale of the unit and not the unit itself was incompatible to what was being measured e.g. the length of Sweden on foot and the length of a football field in inches. Students' responses was however partially yes and partially no, when the unit suggested was not suitable to what was measured e.g. measuring daytime in kilograms and age in decimeters. These responses seemed to however corroborate the theory of measure Lotta's students were articulating all along in nascent terms (Lehrer et al. 2003). They seemed to articulate time and again in the plenary that there needs to be a numerical correspondence between the magnitude of what was being measured and the number of units in which any measurement was being made.

\section{Discussion and conclusion}

We acknowledge Lotta's plenary conduct to have been a microcosm of learning, the sociological importance of which Collins and Pinch (1993) drew attention to. Yet we also find it's CHAT based design, conduct and analysis to be just as insightful. By design Lotta's plenary made it possible for 10-11 year old students at grade four, to question societal norms of measurement which they were learning to acquaint themselves with. The 
timing of such inquiry also followed their having made measurements in the concrete, placing them in a position to reflect at a remove from the meaning of what they were carrying out in various acts of measurement (Wells 1999). In addition to procedural aspects, encouraging students' use of talk for this purpose extended their doing science in language (Lemke 1990). Such a collective parley lasted for almost an hour enabling them to come back time and again, to a theory of measure wherein they were able to speak of underlying conceptual aspects (Lehrer 2003). Their recognition of a need for numerical correspondence between the magnitude of what was being measured and the number of units in which measurements were made, had potential to be an idea that they could use in instrumental ways, in subsequent learning in relation to measures and corresponding measurements (Lehrer et al. 2003). While our suggesting improbable scenarios in the ten questions may have made students' thinking productive, we argue the manner in which Lotta conducted her plenary to be just as important. Six aspects appear to be significant here. First, even as her students came to respect her authority and ground rules, Lotta's students did use exploratory talk (Barnes 2008) by means of which personal experience became part of accounting for themselves and what they knew (Mercer 2002). Such manner of sharing made students view various measures and acts of measurement as their improvable object (Wells 2002). It was also possible for students to examine their understanding which was bound in personal, immediate, holistic and intuitive ways (Wells 1999). Second, dialogic inquiry was vital opportunity for Lotta's students to become critical, democratic and reflective, wherein their observations and thoughts while mediated and challenged by Lotta, were also ridiculed at times by their peers (van Oers 2009). Third, such manner of social interaction became integral part of students' knowledge and repertoire of how various measures and units were objects-that-could-be-used-for-a-certain-purpose (Stetsenko 1999). As evidenced, a large part of Lotta's plenary was spent in students debating and differentiating finer aspects of units, their scale and their magnitude, and whether a unit or its scale was appropriate in making measurements in scenarios that were suggested. Fourth, Lotta's plenary of talk resulted in students articulating a theory of measure, an aspect which seemed possible only under her guidance and supervision. As argued by Karpov (2003a), Lotta's plenary was leading activity, one appropriate for her to lead their intellectual development as middle school students. It could also be argued that a discussion like the one Lotta steered may have been quite unlikely if her students were on a family vacation or taking part in out of school practices and activities. Fifth, the numerous ways in which Lotta's students wrestled with formal-logical thought within leading activity was deeply intertwined with their identities, evidenced in terms of their being skeptical, being able to imagine the plenary as a space in which anything could happen or in professing knowledge of radioactive decay, way beyond prevailing curricular expectations (van Oers 2009). Finally, the transition Lotta's students were making almost ceaselessly between spontaneous and scientific concepts, seemed to parallel the transition they would be making between practitioner and theorist (Karpov 2003b). Generalised, systematic and scientific concepts, be they in the form of a meter ruler, English inch or decimal fractions, helped create the zone of proximal development for students' personal and unorganised knowledge in the form of spontaneous concepts. However both transitions were vital, as Vygotsky (1978) argued, in leading the development of various internal psychological functions of students, in what could understandably be a ceaseless and lifelong dialectic.

We reflect in conclusion on the manner in which we conducted our Formative intervention (Engeström 2011) in line with which Lotta's plenary was not pre-determined but conceived within her curricular realities. While Sharada has spoken to the importance of taking action by drawing on practitioner collaboration and our becoming stakeholders in 
each other's professional practices in such conduct (Gade 2014) she has also discussed the possibility of attending to Lotta's agency as teacher, besides that of her students, by drawing on Engeström's activity theory (Gade 2016). Either aspect supported our conduct of successive interventions which were based on the CHAT driven theory of explicit mediation, wherein by design, students had opportunity to become conscious of their use of underlying concepts (Wertsch 2007). In repeated use of a pedagogical idea that was found feasible in Lotta's instructional realities, we acknowledge the importance of our extended, project related, teacher-researcher collaboration, one portrayed in this paper and conceived as expansive learning activity in addition (Gade 2015). Yet we turn to one final CHAT perspective, which argues for the importance of understanding the concrete existence of Lotta's plenary, in terms of abstract inner laws which may be playing a constituent part (Luria 1979). Towards these aims we conceive Lotta's plenary as a landscape of teachinglearning constituted by a four way dialectic of talk, pedagogy, teaching and learning. With every intention of making a comprehensive study of such a multilectic in due course, we presently make a brief portrayal of this landscape. First and from the five categories of talk identified by Pierce and Gilles (2008) the use of exploratory talk in her plenary enabled Lotta's students to examine their personal understanding of everyday measures and measurements in both individual and collective ways, the nuanced nature of which is worthy object in our further investigation (Mercer 2013). Second and from the five categories of pedagogy recognised by Dalton and Tharp (2002), Sharada found Lotta to have utilised the category termed making meaning connecting school to students' lives, almost without researcher prompt. Not only did this allow Lotta to work with misconceptions that her students presently held, her adopting such a stance enabled her to elicit advanced concepts her students may be familiar with in their personal spiral of knowing (Wells 2002). Lotta's plenary next incorporated three teaching styles identified by Alexander (2008) as initiation of students into canonical ways of human knowing, facilitation of students' intellectual development and acceleration of their grasp of scientific concepts. Such guidance had potential to prepare them to meet the demands democratic societies make on all of us as individuals (van Oers 2009). Finally, of the four categories of learning which van Oers (2008) identifies, Lotta's students learnt to make meaning of concepts which underpinned societal norms and cultural practices in relation to everyday measures and measurement (Lehrer 2003). We argue the manner of talk, pedagogy, teaching and learning instantiated in Lotta's plenary to together constitute a landscape of meaning making. We argue too that such dialectical understanding aids wholistic conceptualisation of not just Lotta's plenary, but a variety of teaching-learning landscapes which classroom teachers orchestrate worldwide. The significance of such insightful efforts, we finally argue, lies in the potential each landscape has in leading students' development, which lies at the very heart of CHAT perspectives and research.

Open Access This article is distributed under the terms of the Creative Commons Attribution 4.0 International License (http://creativecommons.org/licenses/by/4.0/), which permits unrestricted use, distribution, and reproduction in any medium, provided you give appropriate credit to the original author(s) and the source, provide a link to the Creative Commons license, and indicate if changes were made.

\section{References}

Alexander, R. (2008). Towards dialogic teaching: Rethinking classroom talk (4th ed.). Dialogos: UK. Anderson, G. L., Herr, K., \& Nihlen, A. S. (2007). Studying your own school: An educator's guide to practitioner action research. Thousand Oaks, California: Corwin Press. 
Bakhurst, D. (1986). Thought, speech and the genesis of meaning: On the 50th anniversary of Vygotsky's 'Myšlenie I Reč'. Studies in Soviet Thought, 31(2), 103-129. doi:10.1007/BF01046370.

Barnes, D. (2008). Exploring talk for learning. In N. Mercer \& S. Hodgkinson (Eds.), Exploring talk in school (pp. 1-15). Cornwall: Sage.

Clements, D., \& Sarama, J. (2009). Learning and teaching early math: The learning trajectories approach. New York: Taylor and Francis.

Collins, H., \& Pinch, T. (1993). The Golem: What everyone should know about science. Cambridge: Canto.

Dalton, S., \& Tharp, R. (2002). Standards for pedagogy, research and practice. In G. Wells \& G. Claxton (Eds.), Learning for life in the 21st century (pp. 181-194). Cornwall: Blackwell Publishers.

Denzin, N. K. (1989). The research act: A theoretical introduction to sociological methods. Chicago: Aldine Publishing.

Engeström, Y. (2001). Expansive learning at work: Toward an activity theoretical reconceptualization. Journal of Education and Work, 14(1), 133-156. doi:10.1080/13639080020028747.

Engeström, Y. (2011). From design experiments to formative interventions. Theory and Psychology, 21(5), 598-628. doi:10.1177/0959354311419252.

Freire, P. (2005). Pedagogy of the oppressed-30th anniversary edition. London: Penguin.

Gade, S. (2010). Narratives of students learning mathematics: Plurality of strategies and a strategy for practice? In C. Bergsten, E. Jablonka, \& T. Wedege (Eds.), Mathematics and mathematics education: Cultural and social dimensions. Proceedings of the seventh mathematics education research seminar MADIF7 (pp. 102-112). Stockholm: Stockholm University.

Gade, S. (2012). Teacher researcher collaboration at a grade four mathematics classroom: Restoring equality to students usage of the '=' sign. Educational action research, 20(4), 553-570. doi:10.1080/09650792. 2012.727644.

Gade, S. (2014). Practitioner collaboration at a Grade four mathematics classroom: By way of relational knowing and relational agency. In F. Rauch, A. Schuster, T. Stern, M. Pribila, \& A. Townsend (Eds.), Promoting change through action research (pp. 35-47). Rotterdam: Sense Publishers.

Gade, S. (2015). Unpacking teacher-researcher collaboration with three theoretical frameworks-A case of expansive learning activity? Cultural Studies of Science Education, 10(3), 603-619. doi:10.1007/ s11422-014-9619-7.

Gade, S. (2016) School change and educational reform: How activity theory could respond to Sarason's insights. Da Investigação às Práticas: Estudos de Natureza Educacional. Lisbon: Portugal.

Gade, S., \& Blomqvist, C. (2015). From problem posing to posing problems by way of explicit mediation in Grades four and five. In F. M. Singer, N. Ellerton, \& J. Cai (Eds.), Mathematical problem posing: From research to effective practice (pp. 195-213). New York: Springer. doi:10.1007/978-1-4614-6258-3_9.

Karpov, Y. (2003a). Development through the lifespan: A neo-Vygotskian approach. In A. Kozulin, B. Gidnis, V. Agayev, \& S. Miller (Eds.), Vygotsky's educational theory in cultural context (pp. 138-155). New York, NY: Cambridge University Press.

Karpov, Y. (2003b). Vygotsky's doctrine of scientific concepts: Its role for contemporary education. In A. Kozulin, B. Gidnis, V. Agayev, \& S. Miller (Eds.), Vygotsky's educational theory in cultural context (pp. 65-82). New York, NY: Cambridge University Press.

Kozulin, A. (1990). Vygotsky's psychology: A biography of ideas. New York: Harvester Wheatsheaf.

Lehrer, R. (2003). Developing understanding of measurement. In J. Kilpatrick, W. G. Martin, \& D. Schifter (Eds.), A research companion to principles and standards for school mathematics (pp. 179-192). Reston, VA: NCTM.

Lehrer, R., Jaslow, L., \& Curtis, C. (2003). Developing and understanding of measurement at the early grades. In D. Clements \& G. Bright (Eds.), Learning and teaching measurement: 2003 Yearbook (pp. 100-121). Reston, VA: NCTM.

Lemke, J. (1990). Talking science: Language, learning and values. Norwood: Ablex Publishing.

Luria, A. R. (1979). The making of mind: A personal account of Soviet psychology. Cambridge, Massachusetts: Harvard University Press.

Mercer, N. (2002). Developing dialogues. In G. Wells \& G. Claxton (Eds.), Learning for life in the 21st century (pp. 141-153). Cornwall: Blackwell Publishers.

Mercer, N. (2004). Sociocultural discourse analysis: Analyzing classroom talk as a social mode of thinking. Journal of applied linguistics, 1(2), 137-168. doi:10.1558/japl.2004.1.2.137.

Mercer, N. (2008). The seeds of time: Why classroom dialogue needs a temporal analysis. Journal of the learning Sciences, 17(1), 33-59. doi:10.1080/10508400701793182.

Mercer, N. (2013). The social brain, language, and goal-directed collective thinking: A social conception of cognition and its implications for understanding how we think, teach, and learn. Educational Psychologist, 48(3), 148-168. doi:10.1080/00461520.2013.804394. 
Mercer, N., \& Dawes, L. (2008). The value of exploratory talk. In N. Mercer \& S. Hodgkinson (Eds.), Exploring talk in schools (pp. 55-71). London: Sage.

Moll, L. C. (2001). Through the mediation of others: Vygotskian research on teaching. In V. Richardson (Ed.), Handbook of research on teaching (4th ed., pp. 111-129). Washington DC: American Education Research Association.

Mortimer, E., \& Scott, P. (2003). Meaning making in secondary science classrooms. Maidenhead: Open University Press.

Pierce, K., \& Gilles, C. (2008). From exploratory talk to critical conversations. In N. Mercer \& S. Hodgkinson (Eds.), Exploring talk in school (pp. 37-54). Cornwall: Sage.

Stetsenko, A. P. (1999). Social interaction, cultural tools and the zone of proximal development: In search of a synthesis. In S. Chaiklin, M. Hedegaard, \& U. Juul Jensen (Eds.), Activity theory and social practice: Cultural historical approaches (pp. 235-252). Aarhus: Aarhus University Press.

van Oers, B. (2008). Learning and learning theory from a cultural-historical point of view. In B. van Oers (Ed.), The transformation of learning: Advances in cultural-historical activity theory (pp. 3-12). Cambridge: Cambridge University Press.

van Oers, B. (2009). Developmental education: Improving participation in cultural practices. In M. Fleer, M. Hedegaard, \& J. Tudge (Eds.), World yearbook of education 2009: Childhood studies and the impact of globalization: Policies and practices at global and local levels (pp. 213-229). Oxon: Routledge.

Vygotsky, L. S. (1978). Mind in society: The development of higher psychological processes. Cambridge, Massachusetts: Harvard University Press.

Wells, C. G. (1999). Dialogic inquiry: Towards a sociocultural practice and theory of education. New York: Cambridge University Press.

Wells, G. (2002). Inquiry as an orientation for learning, teaching and teacher education. In G. Wells \& G. Claxton (Eds.), Learning for life in the 21st century (pp. 197-210). Cornwall: Blackwell Publishers.

Wertsch, J. V. (2007). Mediation. In H. Daniels, M. Cole, \& J. V. Wertsch (Eds.), The Cambridge companion to Vygotsky (pp. 178-192). Cambridge: Cambridge University Press.

Sharada Gade is currently assistant professor in mathematics education, at Umeå University, Sweden. In collaboration with teachers largely at middle grades she has conducted close-to-practice classroom research since 2008. Such work falls at the intersection of three domains, namely CHAT perspectives, practitioner inquiry and mathematics education. Subsequent to doctoral work from the Univesity of Agder, Norway, Sharada has held visiting postdoctoral fellowships at Homi Bhabha Centre for Science Education (TIFR), Mumbai, India; Umeå Mathematics Education Research Centre, Umeå University, Sweden; The Graduate Centre, City University of New York, USA and the Department of Education, University of Oxford, UK.

Charlotta Blomqvist is presently rektor at Grisbacka elementary school, Umeå, Sweden. Prior to this and for over a decade she taught mathematics, swedish, science, history and english at Berghem elementary school, Umeå. Her expertise includes working as a developer of mathematics at Umeå municipality and as expert at the Swedish National Agency for Education, Skolverket, Stockholm. 